\title{
Rural Livelihoods Vulnerabilities and Commercial Bushmeat Hunting Challenges in Cross River National Park, Nigeria
}

\author{
Oliver 0. O. Enuoh ${ }^{*}$, Francis E. Bisong2 \\ ${ }^{1}$ Tropical Ecological Consult, Abuja, Nigeria \\ ${ }^{2}$ Department of Geography and Environmental Science, University of Calabar, Calabar, Nigeria \\ Email: *oliverenuoh@yahoo.com, febisong@yahoo.com
}

Received 15 August 2014; revised 17 September 2014; accepted 29 September 2014

Copyright (C) 2014 by authors and Scientific Research Publishing Inc.

This work is licensed under the Creative Commons Attribution International License (CC BY). http://creativecommons.org/licenses/by/4.0/

(c) () D Den Access

\begin{abstract}
Biodiversity conservation in parks and protected areas in Africa in general and especially in Nigeria is seriously threatened by the explosion of commercial bushmeat hunting activities in buffer zone communities. Several fauna species are becoming endangered and the list of extinct species is increasing due to commercial bushmeat hunting activities. Using a combination of qualitative and quantitative research techniques, this paper assesses the livelihoods vulnerability underpinnings of commercial bushmeat hunting activities in Cross River National Park (CRNP). Results reveal that commercial bushmeat hunting activities are shaped by a vulnerability context that hinges on different elements of environmental shocks, seasonal challenges and surrounding societal trends. The paper highlights the conservation and global sustainable development implications of uncontrolled commercial bushmeat hunting practices and concludes with options on policy recommendations and future research trajectories.
\end{abstract}

\section{Keywords}

Biodiversity, Livelihoods, Vulnerability, Bushmeat, Hunting

\section{Introduction}

Cross River National Park (CRNP) in south eastern Nigeria is a global biodiversity hotspot and region of species endemism. The park is contiguous in landmass with the Korup National Park and Takamanda Forest Reserve of the Republic of Cameroon. Fauna species like the Cross River Gorilla (gorilla gorilla diehli) are not found

\footnotetext{
"Corresponding author.
}

How to cite this paper: Enuoh, O.O.O. and Bisong, F.E. (2014) Rural Livelihoods Vulnerabilities and Commercial Bushmeat Hunting Challenges in Cross River National Park, Nigeria. Natural Resources, 5, 822-836. 
anywhere else on planet Earth. The wildlife resources of CRNP are seriously threatened by commercial bushmeat hunting activities in buffer zone communities of the park. The paper assesses rural livelihoods vulnerabilities and commercial bushmeat hunting challenges in buffer zone communities of Cross River National Park. Targeted fauna species by hunters include large mammals (e.g. elephants, buffalos, antelopes, bush pigs, duikers, gorillas, chimpanzees and assorted monkeys). Fauna species like leopards, giant pangolin, black deer, and bush cow are no longer seen or have become extinct in Cross River National Park due to commercial bushmeat hunting challenges [1].

The paper starts with literature review that offers a synopsis on African biodiversity conservation and commercial bushmeat hunting challenges, followed by a brief overview on the livelihoods and vulnerability context of commercial bushmeat hunting activities. Insights on the nature of the problem in some African countries are provided which include Ghana, Cote d'Ivoire, Nigeria, Cameroon, Kenya, Equatorial Guinea, Gabon, Democratic Republic of Congo, Tanzania and South Africa. The ecological impacts of commercial bushmeat hunting activities are highlighted, followed by a presentation of methods of the study. This is followed by details on the results of the study and the discussion section. The paper concludes with highlights on the dangers facing African biodiversity conservation and the global sustainable development agenda, as a result of commercial bushmeat hunting activities, and offers recommendations on policies and future research trajectories on the subject. In a nutshell, the paper argues that commercial bushmeat hunting challenges are seriously underpinned by livelihoods vulnerabilities (which ought to be addressed) and that authoritarian park protection measures alone cannot overcome or solve the problem.

\subsection{African Biodiversity Conservation and Commercial Bushmeat Hunting Challenges}

African biodiversity has become highly threatened by commercial bushmeat hunting activities in parks and protected areas, culminating in increasing international attention on the problem, drawn by conservation organisations, development agencies, and natural and social science researchers. Reference [2] estimates that the current harvest of bushmeat in Central Africa amounts to more than 1 million tonnes annually - the equivalent of almost 4 million head of cattle. They stress that local, national and regional trade in bushmeat has become a significant part of the informal sector's hidden economy and that in West and Central Africa alone, the estimates range from $\$ 42$ to $\$ 205$ million a year. On the strength of the above, fauna species' roles in tropical ecosystems functions, stability and resilience are being extremely undermined by commercial bushmeat hunting activities in Africa $[2]$.

Commercial bushmeat hunting by villagers in and around African of parks and protected areas has become a major source of tension and persistent conflicts between park managers and buffer zone communities. It is a major factor responsible for declining and extinct animal populations across Africa [2]-[4]. A typical example is in Kilum Ijim, Cameroon, where many large mammalian species like elephants, gorillas and other primate species, have been extinct in the last fifty years as a result of hunting and alterations in land use [5]. Reference [6] maintains that the future of national parks in Northern Cameroon looks "grim" as the parks are "unable to prevent a vast bushmeat trade organized by poachers". In Ghana, 385,000 tons of wild fauna are hunted yearly [7]. The annual estimate for Cote d'Ivoire is 118,000 tons [8]. To demonstrate the gravity of the problem in Tanzania, [9] reported that within two-month duration (in the middle of 1990), 9600 poachers were arrested in Biharamulo and Ngara districts (7480 later escaped). Hunting items confiscated include 17,321 wire snares, 2007 spears, 1003 bows, 1220 arrows, 900 knives, 205 machetes and 501 axes. Generally, hunting practices are said to be highly unsustainable [10]-[13].

Reference ([3], p. 20) maintains that "lack of documentation has been catalyzed by the illegal nature surrounding the utilization and trade of bush meat. Communities are well aware of the penalties for bushmeat use, and consequently are adverse to revealing information on the activity to outsiders. This has contributed to the general lack of bushmeat related research conducted in the countries of this study. The result has been a continued perception by many, that bushmeat utilization and trade is of limited concern."

Plants and animals are two very important components of biodiversity in any given ecosystem. Reference ([14], p. 102) maintain that in forest ecosystems, "the dissemination of each plant species depends on the eating habits of the animal vectors, their routes, resting places, etc. Many plants with large seeds depend upon large mammals such as monkeys, big birds (toucans, agamis), for their dissemination. The disappearance of these intensively hunted animals may therefore result in a decline in plant diversity". A number of hypotheses have been 
proposed by ecologists which explain the relationships between species richness and ecosystem functions ([14] p. 103):

1) The "diversity-stability" hypothesis upholds that "the productivity of ecological systems and their capacity to react to disturbance increase steadily with a rise in the number of species in the system".

2) The "rivet" hypothesis is derived through analogy: "An airplane wing has more rivets than are actually necessary to hold the wing together. If rivets are progressively eliminated, this may cause the wing to collapse suddenly, once a certain threshold is past." Thus there may be a global ecological collapse if unsustainable biological species extraction around the world is not controlled.

3) The "drivers and passengers" hypothesis emanates from the principle that species play different roles in an ecosystem: "Many species are superfluous (passengers), while only some (drivers) play an essential role in maintaining the ecosystem as a whole. Species with more important ecological functions include, for example, ecological engineers and keystone species. Their presence or absence determines the stability of an ecological function."

4) The final hypothesis (idiosyncratic hypothesis) "considers the possibility that no relationship exists between the species diversity of an ecosystem and how it functions. Ecosystem system functioning is modified when biological diversity changes; however, the magnitude and direction of the modification are not predictable, because the role of each species is unpredictable and may vary from one area to another".

Reference ([2], p. 12) maintains that hunting impacts on a biological community include loss of pollinators (e.g. large bats), seed predators (e.g. pigs, peccaries, agoutis, large squirrels), seed dispersers (e.g. primates, frugivorous bats, frugivorous birds, forest ungulates), and disruption of evolutionary processes. In his study of bushmeat utilization across seven African nations, Reference ([3], p. 34) highlights the conservation implications of commercial bushmeat hunting as follows:

1) Declining animal populations, and exacerbation of depletion and extinction rates.

2) Rising prices of bushmeat which "have motivated hunters and traders to maintain supply from an ever increasing variety of species from ever decreasing populations".

3) Intense hunting pressure in parks and protected areas by villagers, violation of wildlife management laws, and frequent conflicts with park management staff.

4) Perpetration of unsustainable and profit driven hunting practices which seriously undermine biodiversity conservation objectives, and promote failure of integrated conservation and development (ICDPs) initiatives embarked upon by parks and protected areas.

\subsection{The Livelihoods Context of Commercial Bushmeat Hunting Challenges}

Reference ([15], p. 16) maintains that "Livelihoods are the mechanisms through which people translate natural resources into the things they need to survive and thrive". The definition by Chambers and Conway is however the most widely accepted: "A livelihood comprises the capabilities, assets (including both material and social resources) and activities required for a means of living. A livelihood is sustainable when it can cope with and recover from stresses and shocks and maintain or enhance its capabilities and assets both now and in the future, while not undermining the natural resource base" [16].

The commercialization and utilization of bushmeat in many developing nations remains a frontline issue at the intersection between biodiversity conservation, livelihoods and food security [17]. Elaborate research has highlighted the ever increasing utilization of bush meat in different parts of Africa [3] [18]-[20]. Bushmeat plays a leading role in local food security, engages more people than any other wildlife activity, and significantly contributes towards rural revenue generation [21]. Wild animal products constitute important items for consumption or display and have rich medicinal and spiritual values in several human cultures [22]. Across nations in the tropical world, "many people benefit from wild meat: from those who eat it as part of a forest-de- pendent life-style, to those who trade and transport it at all points along different supply chains, to those who consume it in restaurants and homes, often far from the forest" ([2], p. 13).

Reference ([23], p. 52) comments that rural poverty "has its roots in the loss of rights to resources that rural communities have traditionally considered their own". It is these rights to timber, water, land and wildlife that are essential elements to sustainable development. The starting point in the protected area-poverty debate is to recognise that the cost of protected areas is often at the expense of the poor (e.g. through expropriations of their land or by having them deliver global public goods for free)". Reference ([24], p. 152) empirically analysed the 
opportunity costs of biodiversity conservation in Kenya and discovered that if Kenya were to use her parks, reserves and forest lands to support agricultural and livestock production, the country would generate annual revenues of $\$ 565 \mathrm{~m}$, and net returns of $\$ 203 \mathrm{~m}$. Kenya's combined net revenues from wildlife tourism and forestry amounted to $\$ 42 \mathrm{~m}$, implying that $\$ 203 \mathrm{~m}$ is the opportunity costs to Kenya per annum for conserving biodiversity. The authors conclude that "given the global nature of the benefits from Kenya's conservation efforts, it is quite inappropriate that so much of the cost is borne by Kenya".

\subsection{The Vulnerability Context of Commercial Bushmeat Hunting Challenges}

Reference ([25], p. 155) maintains that the term "vulnerability is conceptualized in very different ways by scholars from different knowledge domains, and even within the same domain". For example, whereas social science scholars apply the term in contexts of specific explanatory models, engineers and natural scientists do so in a descriptive manner [26]. Though methods of vulnerability assessment have been developed over the past several decades in natural hazards, food security, poverty analysis, sustainable livelihoods and related fields, vulnerability has no universally acceptable definition [27]. In climate change research, which entails intense collaboration between scholars from many different research traditions, including climate science, risk assessment, development, economics, and policy analysis, "the existence of competing conceptualizations and terminologies of vulnerability, has become particularly problematic" ([25], p. 156).

Reference [28] observes that vulnerability "has been related or equated to concepts such as resilience, marginality, susceptibility, adaptability, fragility, and risk". Reference ([29], p. 46) argues that "it is vital to recognise that vulnerability should be treated as a condition of people that derives from their political-economic position". It is therefore "dangerous" to use it loosely or as a characteristic of exposure to hazard alone, since this allows the key components of power and income distribution to be played down and prominence given to technical fixes". As it relates to livelihoods, ([30], p. 249) defines vulnerability as the "exposure of individuals or collective groups to livelihood stress as a result of social and environmental change, where stress refers to unexpected changes and disruption to livelihoods".

Reference [31] maintains that the vulnerability context frames the environmental stresses (Shocks, Seasonality and Trends) that impact on people's livelihoods assets and strategies, for which they have limited or no control. Elements of shocks, seasonality and trends include:

- Trends: e.g. Population trends, resource trends (including conflict), national and international economic trends, political (governance) trends and technological trends. Trends may have serious effects on rates of return (economic or otherwise) on livelihood activities.

- Shocks: e.g. Human health shocks, natural shocks, economic shocks, conflict and crops/livestock health shocks. Shocks such as floods, storms, civil conflict, drought, etc., can force people to migrate prematurely, as a form of coping strategy.

- Seasonality: e.g. of prices, production, health and employment opportunities. Seasonal change in prices, employment opportunities and availability of food constitutes a serious source of hardship to poor people.

From the above, suffice it to say that the degree of vulnerability of the poor is determined by multiple factors closely related to trends, shocks, and seasonality concerning economic, social, political, geographical, and natural resource factors [31]. Reference [31] concludes that many of the hardships faced by the poorest people in the world are directly or indirectly traceable to their vulnerability context.

\subsection{Buffer Zone Communities of Parks and Livelihoods Vulnerabilities}

In forest communities, where there are no formal insurance services, social security, or social welfare schemes, [32] maintains that forests provide two types of insurance to local people: 1) liquid assets by way of non-timber forest products (NTFPs) which include bushmeat; 2) non-liquid assets by way of forest goods and services that support other livelihood strategies and household security. Reference ([33], p. 490) stresses that "access by the landless and rural poor to basic subsistence resources - farmed and gathered food, fodder, water, fuel, building materials, medicines, raw materials for tools and house wares - is essential for livelihood security". In times of natural, economic and social adversities, local people usually resort to cost-saving forest-based activities to fill household revenue gaps that social capital and networks cannot fill [34].

In support of the above argument, [35] comments that households livelihood security is dependent on different wild foods that supplement diets, on medicinal plants for human and livestock treatments, on construction 
materials, and on the sale of assorted forest products to fill revenue gaps or provision of subsistence cash. Reference [36] maintains that in the livelihoods of forest peoples, knowledge is still inadequate on: 1) what proportion of rural households use NTFPs as informal insurance or safety-net; 2) who depends on NTFPs as safety-net and how is this dependent on household characteristics; 3) current NTFPs use, and its effect on the safety-net role; 4) different manifestations of the safety-net roles (whether by increased use or by sale of forest products); 5) when (time dynamics) and circumstances people turn to NTFPs as informal insurance; 6) different forest types and its effects on NTFP abundance or availability for informal insurance services; 7) institutional contexts and its impacts on safety-net functions of NTFPs; 8) market contexts, and its impacts on safety-net functions of NTFPs. On the strength of the above, [37] argues that in the context of rural livelihoods, the informal insurance (safety-net) functions of forests must not be disrupted or endangered without the provision of viable alternatives.

\subsection{Coping with Vulnerability}

Reference ([38], p. 157) maintains that "rural communities are not homogenous units, rather, within any given community there are numerous factors that distinguish households and determine their livelihood strategies, their vulnerability context, their access to resources and their ability to cope". Coping mechanisms comprise preventive, impact-minimising or post event coping measures adopted by households, for the management of external livelihood shocks [39]. Such mechanisms are "characterised by considerable resilience - the ability to return to a former livelihood, on the basis of a diversity of income and food sources - and accumulated skills, including knowledge of wild foods and kinship networks" ([40], p. 1234). Reference ([38], p. 155) summarises coping strategies used by rural households (see Table 1 ) in response to a variety of risks.

Commenting on the relative effectiveness of household vulnerability coping strategies, [41] maintain that the measures address small scale shocks, and fail, when confronted with medium to large scale shocks. The rural poor are insufficiently insured in the developing world, and public safety-nets are weak or malfunction, compelling households to rely on informal insurance strategies for survival [42]. Rural households use non-timber forest products (NTFPs), which includes bushmeat, as social safety net or informal insurance, when confronted with external shocks [38]. It is instructive to note that in CRNP [1] maintains that apart from hunting, limited employment opportunities exist in the buffer zone communities.

\section{Table 1. Coping strategies used by rural households in response to different risks.}

\begin{tabular}{|c|c|}
\hline Coping Strategy & References \\
\hline 1) Kinship and community-support networks and the reciprocity of money, goods, land and labour & [31]-[44] \\
\hline 2) The sale of assets (including livestock) & [42]-[45] \\
\hline 3) The use and/or sale of NTFPs & {$[30]-[52]$} \\
\hline 4) Out migrations and remittances & {$[30]-[42]$} \\
\hline 5) Livelihood diversification & {$[30][53]$} \\
\hline $\begin{array}{l}\text { 6) Redistribution/reallocation of labour, the removal of children from school, the relocation of dependents to } \\
\text { extended family and the adoption of children }\end{array}$ & {$[42]-[55]$} \\
\hline 7) Saving schemes, stokvels (credit groups), buying on credit and the withdrawal from stokvels to save on payments & [32]-[56] \\
\hline 8) Agricultural diversification, changes in agricultural practices, changes in crop type and food storage & [32]-[44] \\
\hline $\begin{array}{l}\text { 9) Changes to household spending and food consumption (including changes to both the quantity and quality of } \\
\text { meals as well as reductions in the number of meals consumed) }\end{array}$ & [41] \\
\hline 10) Wage labour & [42] [44] \\
\hline 11) Selling food, goods and services (including prostitution) & [40] [44] \\
\hline
\end{tabular}

Source: [38], p. 155. 


\section{Methods}

The study was carried out in three local communities (two in the buffer zone and one outside the buffer zone) of Cross River National Park in Nigeria. The two buffer zone communities are Abo Mkpang and Old Ekuri, while Akwa Ibami is the non-buffer zone community (chosen for comparative purposes). Field research activities was preceded by a reconnaissance exercise on bushmeat hunting in buffer zone villages which culminated in purposive sampling selection of two communities in Oban division (Old Ekuri and Akwa Ibami), and one in Okwangwo division (Abo Mkpang). The above was also based on prior knowledge of local communities with markets for bushmeat in Cross River State, Nigeria. Reference ([57], p. 202) maintain that "many qualitative researchers employ ... purposive, and not random, sampling methods. They seek out groups, settings and individuals where the processes being studied are most likely to occur".

A combination of quantitative and qualitative techniques was used for data collection. On quantitative method, a household survey of current livelihood strategies in the sampled communities was carried out. The list of registered voters (more current than census data) was used as sample frame, and proportional to the voting population size of the sampled communities, a sample size of 267 was chosen. The sampled villages were stratified, culminating in the identification of groups (e.g. hunters/bush meat traders, Chiefs/village councils, women and youth), to whom questionnaires were randomly and carefully administered.

The qualitative data collection techniques comprised document research, focus group discussions, key informant interviews, participatory rural appraisal exercises and observations. Multiple data collection tools in social research is referred to as triangulation [58] and [59]. It involves collecting "information from multiple sources but aimed at corroborating the same fact or phenomenon" ([58], p. 99). The underlying logic is that "it is better to look at something from several angles than to look at it in only one way" ([59], p. 138). Also, ([60], p. 13) emphasizes that "different methods have different strengths and different weaknesses. If they converge (agree) then we can be reasonably confident that we are getting a true picture".

\section{Results}

Reference [32] indentifies the environmental stresses that impact on local people's livelihoods which comprise shocks, seasonality and trends. Shock elements include natural disasters, human health shocks, economic shocks, intra and inter-communal conflicts, and crop/livestock health shocks. Seasonality elements include seasonal changes in production costs, commodity prices, health care, and availability of employment opportunities. Trends elements include population trends, resource use trends, national/international economic trends, governance trends and technological trends. The following subsections present findings on livelihoods vulnerabilities associated with commercial bushmeat hunting activities in the study villages influenced by some aspects of shocks, seasonality and trends.

\subsection{Shocks}

\subsubsection{Wildlife Pests and Raiding of Agricultural Crops}

Field research evidence (animal footprints on farmlands, dung, hairs, and assorted teeth marks on cassava, yams, plantain and melon) reveal that wildlife pests and persistent raiding of agricultural crops in buffer zone farms undermine agricultural production/output, exacerbate food scarcity, cause poor returns on agricultural investments, and culminate generally in disappointing livelihood outcomes. The Cross River National Park pays no compensation to farmers on the above losses. As a result of the above, buffer zone villagers trespass into the territory of Cross River National Park (as safety net or informal insurance) for different income generating livelihood activities. During participatory rural appraisal exercises in the study villages the names of animals that raid agricultural crops were compiled and is presented in Table 2.

On the strength of the above, the study concludes that persistent wildlife raiding of agricultural crops and disappointing livelihoods outcomes in the buffer zone communities of CRNP creates and sustains a livelihoods vulnerability context that continuously shape and push villagers into commercial bushmeat hunting activities.

\subsubsection{Farmers and Buffer Zone Agricultural Land Conflicts}

Field evidence also reveals that apart from their limited size in the study villages, buffer zone forestlands do not have uniform physical characteristics (e.g. topography, geology, soils, plants species distribution and abundance 
Table 2. Wildlife and crop raiding in buffer zone (study) villages of CRNP.

\begin{tabular}{|c|c|c|}
\hline S/No. & Wildlife Species (Common/Botanical Name) & Crops Consumed/Damaged \\
\hline 1 & Bush Pig (Potamochoerus porcus) & Maize, Yams, Cassava, Sweet Potato \\
\hline 2 & Assorted Monkeys (e.g. Cercopithecus pygerythrus) & Maize, Banana, Plantain, Sugar Cane, Fruits, etc. \\
\hline 3 & Chimpanzees (Pan troglodytes) & $\begin{array}{l}\text { Maize, Banana, Plantain, Sugar Cane, Fruits, } \\
\text { Sweet Potato, Ground nuts, etc. }\end{array}$ \\
\hline 4 & Gorilla (Gorilla gorilla) & $\begin{array}{l}\text { Maize, Banana, Plantain, Sugar Cane, Fruits, } \\
\text { Sweet Potato, Ground nuts, etc. }\end{array}$ \\
\hline 5 & Squirrels (Oenomys, Stochomys, Funisciurus Spp.) & Cocoa, Oil Palm fruits, Banana, Plantain \\
\hline 6 & Giant Rat (Cricetomys Sp.) & Cocoa, Oil Palm Fruits, \\
\hline 7 & Grass Cutter or Cane Rat (Thryonomys swinderianus) & Rice, Cassava, Maize, Sugar Cane \\
\hline 8 & Bongo Antelopes (Tragelaphus euryceros) & Yam Leaves (foraging), Yams \\
\hline 9 & Hippopotamus (Hippopotamus amphibius) & Maize, Rice, Vegetables \\
\hline 10 & Elephants (Loxodonta africana) & Maize, Plantain, Banana, Sweet Potato, Sugar Cane, Fruits, etc. \\
\hline 11 & Drills (e.g. Mandrilus leucophaeus) & $\begin{array}{c}\text { Banana, Plantain, Maize, Sweet Potatoes, Ground Nuts, } \\
\text { Sugar Cane, Fruits, etc. }\end{array}$ \\
\hline 12 & Buffalos (Syncerus nanus) & Yams, Coco Yams, Plantain, Banana, Cocoa, etc. \\
\hline 13 & African Brush-Tailed Porcupines (Atherurus africanus) & Cocoa, Melon \\
\hline 14 & Assorted Bird Species & $\begin{array}{l}\text { Rice, Maize, Cassava, Banana, Plantain, Pawpaw, Groundnuts, } \\
\text { Melon, Vegetables, Fruits (e.g. Pear), etc. }\end{array}$ \\
\hline 15 & Duiker (Cephalophus spp.) & Cocoa \\
\hline 16 & Civet Cat (Viverra civetta) & Cocoa \\
\hline 17 & Assorted Snakes Species & Oil Palm Fruits, Melon, Cocoa, Ground Nuts, etc \\
\hline 18 & Spotted Hyaena (Crocuta crocuta) & Oil Palm, Cocoa \\
\hline 19 & Assorted Rodents Species. & Oil Palm, Cocoa, Melon, Ground Nuts, \\
\hline 20 & Assorted Insects Species (e.g. Grasshoppers, Locusts, etc) & $\begin{array}{l}\text { Rice, Maize, Sugar Cane, Plantain, Banana, Melon, } \\
\text { Ground nuts, Fruits, Yams, etc. }\end{array}$ \\
\hline
\end{tabular}

Source: Field work 2012.

of other biological resources). A key informant discloses that within the buffer zone, some areas are hilly or mountainous, and have rocky outcrop and poor soils that make them unsuitable for agriculture. As the buffer zone territory is fixed, and certain families had scrambled for and acquired the fertile areas in the past, other families were left with no option but to take up the less fertile areas. Interviews at both Abo Mkpang and Old Ekuri reveal that some families continue to relatively do better than others in local food production due to the location of their farms on fertile areas.

Attempts by disadvantaged households to relocate and go into rich agricultural fallow lands belonging to certain families or households, have been resulting in serious conflicts, police cases and court cases. Some household heads attributed their poverty and inability to sell agricultural food crops to disadvantages in farm location. They lament that the richer agricultural lands are in the Cross River National Park territory, which they cannot migrate into. At Old Ekuri examples were cited of some mysterious deaths which they believed were due to land conflicts amongst different households and individuals. A key informant named a certain woman, along with her daughter who is both currently blind due to farm land conflicts with another villager who is alleged to have juju or evil spiritual powers. In an interview, a hunter at Old Ekuri disclosed that he resorts to hunting activities because he hardly generates any income from agricultural activities (due to hilly location and poor soils) and in order to avoid involvement in land conflicts.

At Abo Mkpang village, another hunter commented that when the Cross River National Park promised a live- 
lihoods programme (at its inception in 1989), he developed keen interest in either livestock or fish farming. He said his farmland is in a rocky area, and the soil there is not good for crops like Yams, Plantain and Cassava. That is why he had high hope on livestock or fisheries. But the CRNP and their donor partners (WWF and EU) disappointed them by not implementing the livelihoods programme to this day. He stressed that hunting is the only means of income generation due to land conflicts and the park's inability to implement a robust livelihoods programme with off-land livelihoods options.

\subsubsection{Buffer Zone Forest Land and Limited Non-Timber Forest Products (NTFPs)}

Inequitable distribution of timber and non-timber forest products (NTFPs) in acquired buffer zone forest lands has created a livelihoods vulnerability context where certain families have advantage over others in the control and exploitation of NTFPs. In an interview, a villager at Abo Mkpang disclosed that he hunts because of disadvantages that emanates from parental acquisition and control of resource poor area of their buffer zone forest. He stressed that attempts by disadvantaged households to exploit NTFPs in areas controlled by other families / households usually result in squabbles and violent clashes.

\subsection{Seasonality}

From the PRA exercises and Seasonal Calendar that was produced in each of the villages of this study, it was discovered that there was uniformity in the activities embarked upon by households. This is because the villages are all in the tropical rainforest region of Nigeria, with common weather and climate, flora and fauna species, geology and soil characteristics, local knowledge on biological resources values, and cultural affinity. On the strength of the above, a common seasonal calendar was produced which reflects the reality in each of the communities (see Table 3).

From the above Seasonal Calendar, food is not usually available all year round. Food is available from the

Table 3. Seasonal calendar of income generating activities in buffer zone villages of CRNP.

\begin{tabular}{|c|c|c|c|c|c|c|c|c|c|c|c|c|}
\hline Activities & Jan & Feb & Mar & Apr & May & June & July & Aug & Sept & Oct & Nov & Dec \\
\hline \multicolumn{13}{|l|}{ Agriculture } \\
\hline Clearing/Burning & $\mathrm{X}$ & $\mathrm{X}$ & & & & & & & & & & $\mathrm{X}$ \\
\hline Planting/Sowing & & & $\mathrm{X}$ & $\mathrm{X}$ & $\mathrm{X}$ & & & & & & & \\
\hline Weeding & & & & & & $\mathrm{X}$ & $\mathrm{X}$ & $\mathrm{X}$ & & & & \\
\hline Harvesting & $\mathrm{X}$ & & & & & & & & & & $\mathrm{X}$ & $\mathrm{X}$ \\
\hline Food Availability & $\mathrm{X}$ & $\mathrm{X}$ & $\mathrm{X}$ & $\mathrm{X}$ & & & & & & & $\mathrm{X}$ & $\mathrm{X}$ \\
\hline \multicolumn{13}{|l|}{ NTFP Gathering } \\
\hline Bush Mango & & & & & & $\mathrm{X}$ & $\mathrm{X}$ & $\mathrm{X}$ & $\mathrm{X}$ & $\mathrm{X}$ & & \\
\hline Wild Vegetables & $\mathrm{X}$ & $\mathrm{X}$ & $\mathrm{X}$ & $\mathrm{X}$ & $\mathrm{X}$ & $\mathrm{X}$ & $\mathrm{X}$ & $\mathrm{X}$ & $\mathrm{X}$ & $\mathrm{X}$ & $\mathrm{X}$ & $\mathrm{X}$ \\
\hline Wild Mushrooms & & & & & & $\mathrm{X}$ & $\mathrm{X}$ & $\mathrm{X}$ & $\mathrm{X}$ & $\mathrm{X}$ & $\mathrm{X}$ & \\
\hline Rattan & $\mathrm{X}$ & $\mathrm{X}$ & $\mathrm{X}$ & $\mathrm{X}$ & $\mathrm{X}$ & $\mathrm{X}$ & $\mathrm{X}$ & $\mathrm{X}$ & $\mathrm{X}$ & $\mathrm{X}$ & $\mathrm{X}$ & $\mathrm{X}$ \\
\hline Assorted fruits & & & & & & $\mathrm{X}$ & $\mathrm{X}$ & $\mathrm{X}$ & $\mathrm{X}$ & $\mathrm{X}$ & & \\
\hline Mimosup Oils & & & & & & $\mathrm{X}$ & $\mathrm{X}$ & $\mathrm{X}$ & $\mathrm{X}$ & $\mathrm{X}$ & & \\
\hline \multicolumn{13}{|l|}{ Hunting Activities } \\
\hline Gun & & & & & $\mathrm{X}$ & $\mathrm{X}$ & $\mathrm{X}$ & $\mathrm{X}$ & $\mathrm{X}$ & $\mathrm{X}$ & & \\
\hline Trapping & & & & & $\mathrm{X}$ & $\mathrm{X}$ & $\mathrm{X}$ & $\mathrm{X}$ & $\mathrm{X}$ & $\mathrm{X}$ & & \\
\hline Food Poisoning & $\mathrm{X}$ & $\mathrm{X}$ & $\mathrm{X}$ & & & & & & & & & $\mathrm{X}$ \\
\hline Fishing & $\mathrm{X}$ & $\mathrm{X}$ & $\mathrm{X}$ & & & & & & & & & $\mathrm{X}$ \\
\hline Water Poisoning & $\mathrm{X}$ & $\mathrm{X}$ & $\mathrm{X}$ & & & & & & & & & $\mathrm{X}$ \\
\hline
\end{tabular}

Source: Field work 2012. 
harvesting period (November) up to the end of the planting season (April). From interviews, a combination of factors: wildlife raiding of agricultural crops, crop diseases/crop failure, poor commodity prices, and climate change, all combine to exacerbate food scarcity in the buffer zone communities. At Old Ekuri (30 kilometres of jungle terrain from the highway), it was observed that villagers were always trooping out to farming communities along the highway (e.g. Ochon, Ohana, Apiapum, Ekukunela, etc.) to buy their needs (especially food). The food from their farms is just not enough to sustain them. Accordingly, they resort to hunting activities and use the money to buy food during food scarcity.

The hungry season sets in from May to October (Figure 1). This period corresponds with the six months of hunting season (Figure 2: May to October)/rainy season, when leaves on the forest floor are wet and hunter movements cannot easily be detected by animals, culminating in their being hunted easily. In the dry season (November to April), the forest floor is usually full of dry leaves, which makes noise as hunters walk on them. This always alerts animals, and they usually run away before hunters can see them. This makes hunting difficult. Trapping is also carried out from May to October, as the wet leaves on the forest floor and the moist ground easily show animal pathways and footprints, guiding hunters on where to locate the traps.

\subsection{Trends in Human Population Increase and Pressure on Environmental Resources}

Though Nigeria's national population census figures in the past few decades have been disputed, figures released by the World Bank in 2014 indicate that Nigeria's population is 173.6 million, with an increasing growth

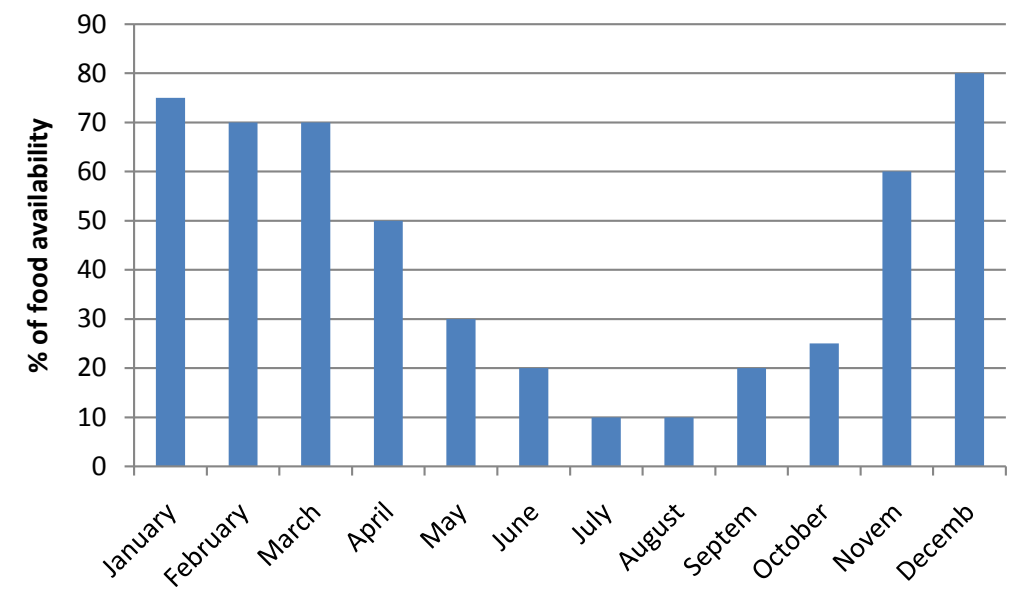

Figure 1. Food availability and hungry season in buffer zone villages of CRNP. Source: Field work 2012.

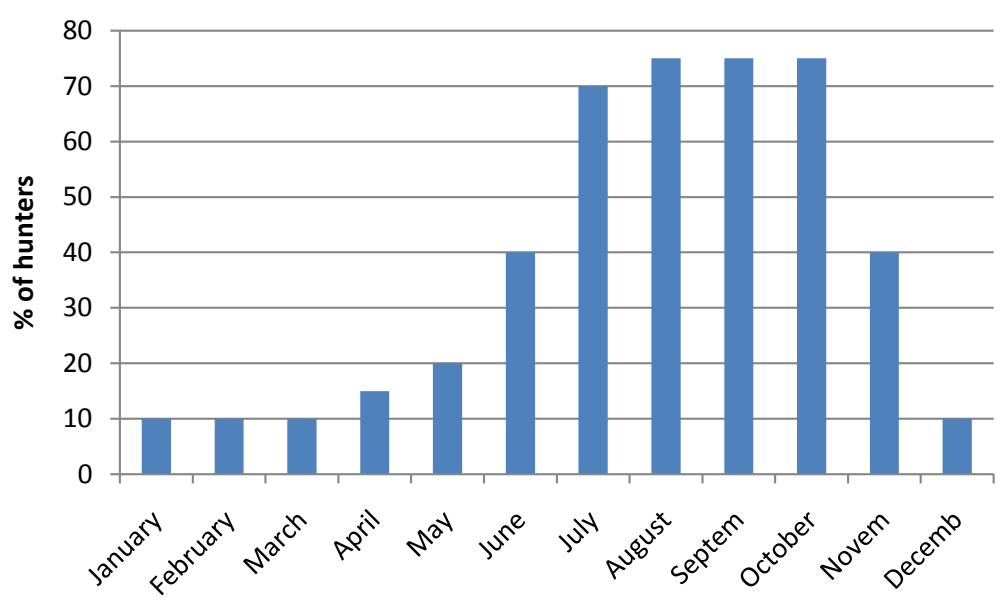

Figure 2. Hunting season corresponding with hungry season. Source: Field work 2012. 
rate trend of 2.7 (in 2009), 2.7 (in 2010), 2.8 (in 2011), and 2.8 (in 2013). Accordingly, Nigeria is said to be experiencing population explosion and has one of the highest growth and fertility rates in the world. The lack of acceptable national census figures makes it difficult to ascertain the true population size of her villages, including the villages of this study. However, a community leader at Old Ekuri commented that the increasing trend in primary school enrolment of pupil in the study villages strongly indicate population increase and confirm the above World Bank data. Given the high unemployment situation in the country, the above population trend has serious implications on pressure on environmental resources (especially commercial bushmeat hunting activities) by rural dwellers.

Analysis of the human population segments involved in commercial bushmeat hunting in the study villages indicate that unemployed secondary school leavers dominate hunting activities in buffer zone communities. In an interview, a teacher at St. Joseph's Primary School, Old Ekuri commented that every year more secondary school leavers return to the village with failed statement of results (West African School Certificate Examination). The school leavers can neither gain admission to tertiary institutions nor get employed in the private or public sectors. All end up becoming hunters in their villages. According to the above teacher, failure in West African School Certificate Examination (WASCE) and youth unemployment have become trend setting events that annually fuel the population of hunters in the study villages.

From field observations, early polygamous marriages are ubiquitous, culminating in high rate of procreation amongst villagers. There are no laws that control or limit how many wives a man can marry, and how many children a man can raise. Villagers have a free hand in procreating more children than they can cater for. There are no family planning programmes or services to assist women on reproductive health matters. Teenage pregnancies are quite normal in the experiences of villagers.

\section{Discussion}

The feasibility study and management plan document of Cross River National Park prepared by WWF/ODNRI in 1989 made provision for a buffer zone or support zone development programme (SZDP) which included rural livelihoods activities and the resettlement of enclave communities (villages located in the core area of the park). The above programme was proposed to take place within the first seven years of the park's existence (19911998). Unfortunately, that period coincided with the time several researchers and reviewers reported in several journals that integrated conservation and development projects (ICDPs) in tropical parks and protected areas were not enhancing the actualization of biodiversity conservation objectives [61]-[64]. On the strength of the above, donors (e.g. WWF and EU) who were to fund SZDP and resettlement activities in Cross River National Park held back their money to this day.

Consistent with renewed calls for authoritarian park protection (away from ICDPs) [61]-[64], tropical parks like Cross River National Park have been struggling to deal with commercial bushmeat hunting challenges in the park through authoritarian means hinging on frequent arrest and punishment of poachers and other trespassers. Due to buffer zone rural livelihoods vulnerabilities, commercial bushmeat hunting activities continue to thrive in CRNP despite the parks commitment to authoritarian park protection. The park is not taking poverty alleviation or livelihoods programmes seriously, after all, there is a school of thought in conservation that tropical biodiversity conservation and poverty alleviation activities are incompatible [65]. However, [66] strongly observes that global rural poverty is highest in areas with the highest concentration of biodiversity in the world. With the UN millennium development goals (MDGs) and global commitment to poverty eradication, ([63], p. 241) stresses that "biodiversity conservation today is challenged to engage with the most important UN Millennium Development Goal, which is to eradicate extreme poverty and hunger." Conservationists are divided, some for, and some against the above.

With the explosion of commercial bushmeat hunting activities in CRNP and worsening depletion and extinction of several fauna resources, conservationists should revisit the parks-poverty debate, in frameworks that recognise 1) the challenges of authoritarian park protection in the context of tropical parks; 2) commercial bushmeat hunting challenges and the need to address livelihoods vulnerabilities in buffer zone communities; 3 ) the widening development gap between rural communities with MDG programmes and buffer zone communities of parks without such programmes (wallowing in poverty); 4) the need to address other anthropogenic contestations in tropical parks (e.g. park establishment on colonially nationalised forest territories and the suppressed property rights of local communities). 
Reference [67] maintains that current tropical biodiversity conservation strategies lack commitment to social justice and human rights. Conservationists and national governments are said to be taking undue advantage of weak and marginalized indigenous and local people that own the forest territories of parks, all struggling to survive in a twenty-first century world — of globalized capitalism and market economy. Promoting tropical biodiversity conservation in parks and protected areas that are based on the nationalization of the natural assets of local people (without compensation), is perceived as unjust [22]. On one hand is the UN Millennium Development Goal on global poverty eradication, while on the other hand is the establishment of parks on colonially nationalized forest territories belonging to local people. Such contradictions, in a world that is committed to poverty eradication and equitable development, are seen as unjust and will continue to be a basis for local resistance to biodiversity conservation in tropical parks [68].

In South Africa, the establishment of Ndumo Game Reserve in 1924 resulted in Mbangweni community (the original land owners) being evicted and dispossessed of their rights to their ancestral lands. Following the end of apartheid in 1994, the South African government negotiated and arrived at a legally binding agreement which "transformed the eastern part of the Ndumo Game Reserve from what was essentially a state property regime to a common property regime" ([69], p. 8), among other benefits. Reference [36] similarly reports that following the end of apartheid in 1994 and litigation over Richtersweld National Park, judgement was arrived at in favour of Nama people (the original land owners). Reference [70] maintains that the negotiations give significant concessions to the Nama People which includes 1) a contractual land agreement which recognised Nama people as land owners; 2) a lease fee of $£ 20,000.00 ; 3$ ) grazing rights for 6600 livestock (mainly goats and sheep); 4) reduction of the size of the park from 2500 to $1625 \mathrm{~km}^{2}$, to allow $800 \mathrm{~km}^{2}$ of additional grazing land; 5) creation of a park management committee that had more Nama representatives than other government appointees; 6) guaranteed job opportunities for Nama people; 7) a duration of 30 years, after which the lease agreement has to be reviewed.

The above example should serve as a lesson to other African parks like Cross River National Park. Reference ([71], p. 1265) strongly stresses a major part of the conflict over wildlife conservation "involves property and property rights", and thus concludes that "the political determination of property regimes is critical to conservation".

\section{Conclusions}

African biodiversity in general and that of Cross River National Park in particular have become highly threatened by commercial bushmeat hunting activities, culminating in increasing international attention on the problem, drawn by conservation organisations, development agencies, and natural and social science researchers. Several fauna species are becoming endangered and the list of depleted and extinct species in Africa continues to increase in the IUCN red list of depleted and extinct species. This paper assesses the livelihoods vulnerability underpinnings of commercial bushmeat hunting activities in Cross River National Park (CRNP). It reveals that commercial bushmeat hunting activities are shaped by a vulnerability context that hinges on different elements of environmental shocks, seasonal challenges and surrounding societal trends. The need for conservation to address the livelihoods vulnerability underpinnings of commercial bushmeat hunting activities in CRNP is stressed.

The paper notes that the feasibility study and management plan document of Cross River National Park prepared by WWF/ODNRI in 1989 made provisions for a buffer zone or support zone development programme (SZDP) which included rural livelihoods activities and the resettlement of enclave communities (villages located in the core area of the park). Unfortunately, the SZDP which was supposed to implement in the first seven years of the park's existence (1991-1998) is yet to be executed. The wider literature on parks - poverty debate and its impacts on people oriented programmes in CRNP is briefly discussed. Policy options for a best way forward are highlighted with insights from South Africa's post-apartheid negotiations and measures that have resolved property rights contestations and other allied sources of conflicts between parks and local communities.

However, further empirical studies are required to ascertain the financial costs associated with annual wildlife raiding of agricultural crops in the buffer zone communities of CRNP. Such data will immensely help to convince the government, donors, and park authorities on the economic impacts of biodiversity conservation on local people and the need to address such problems - in the interest of effective tropical biodiversity conservation initiatives and commitment to the global sustainable development agenda. Wildlife surveys to ascertain the impacts of commercial bushmeat hunting activities on different wildlife populations in CRNP are very important. 
Without such studies, policy measures to address commercial bushmeat hunting activities will continue to be weak as they are now.

\section{Acknowledgements}

This paper is one of the outcomes of my doctoral research programme: "Buffer Zone Communities, Commercial Bushmeat Hunting and Biodiversity Conservation in Cross River National Park, Nigeria". The programme ended in December 2012, at the University of Reading, UK, and its sponsorship by the Commonwealth Scholarship Commission, London, is hereby acknowledged and highly appreciated.

\section{References}

[1] ODNRI/WWF (1989) Cross River National Park Oban Division: Plan for Developing the Park and Its Support Zone. London.

[2] Brown, N.R., Wilkie, D., Bennett, D., Tutin, E., van Tol, C.G. and Christophers, T. (2008) Conservation and Use of Wildlife-Based Resources: The Bushmeat Crisis. Technical Series No. 33, Secretariat of the Convention on Biological Diversity, Montreal, and Centre for International Forestry Research (CIFOR), Bogor, 50 p.

[3] Barnett, R. (2000) Food for Thought: The Utilization of Wild Meat in Eastern and Southern Africa. TRAFFIC East/ Southern Africa, Nairobi, 264.

[4] Murray, M. (2003) Overkill and Sustainable Use. Science, 299, 1851-1853. http://dx.doi.org/10.1126/science.1079823

[5] Maisels, F., Kerming, E., Kermei, M., and Toh, C. (2001) The Extirpation of Large Mammals and Implications for Montane Forest Conservation: The Case of the Kilum-Ijim Forest, North-West Province, Cameroon. Oryx, 35, 322-331. http://dx.doi.org/10.1017/S0030605300032087

[6] David, B. (1995) Wildlife and National Parks in Northern Cameroon. Bois et Forêts des Tropiques, No. 244, 43-54.

[7] Ntiamo-Baidu, Y. (1997) Can Wildlife Contribute to Food Security in Africa? FAO Conservation Guide 33. Food and Agriculture Organisation of the United Nations, Rome.

[8] Caspary, H.U. (1999) Utilisation de la faune sauvage en Cote d'Ivoire et Afrique de I'Ouest. Potentiels et contraintes pour la coopération au développement. Deutsche Gesellschaft fur Technische Zusammenarbeit (GTZ) GmbH, Eschborn.

[9] KEP (1997) Impact Assessment Study in Refugee Affected Districts of Biharamulo, Ngara and Karagwe. Kagera Environmental Project, Tanzania Agro-Industrial Services Limited, Dar es Salaam.

[10] Newing, H. (2001) Bushmeat Hunting and Management: Implications of Duiker Ecology and Interspecific Competition. Biodiversity and Conservation, 10, 99-118. http://dx.doi.org/10.1023/A:1016671524034

[11] Carpenter, G.M., Fusari, A. and Okongo, H. (2007) Subsistence Hunting and Exploitation of Mammals in the HautOgooud Province, South Eastern Gabon. Journal of Anthropological Sciences, 85, 183-193.

[12] Bassett, T.J. (2005) Card-Carrying Hunters, Rural Poverty and Wildlife Decline in Northern Cote d'Ivoire. The Geographical Journal, 171, 71-82. http://dx.doi.org/10.1111/j.1475-4959.2005.00147.x

[13] Redford, K.H. (1992) The Empty Forest. Bioscience, 42, 412-422. http://dx.doi.org/10.2307/1311860

[14] Leveque, C. and Mounolou, J. (2003) Biodiversity. John Wiley and Sons Ltd., Chichester.

[15] Matthew, R., Halle, M. and Switzer, J., Eds. (2002) Conserving the Peace: Resources, Livelihoods and Security. IISD/ IUCN Publication, Gland, Switzerland.

[16] Chambers, R. and Conway, G. (1992) Sustainable Rural Livelihoods: Practical Concepts for the 21st Century. IDS Discusion Paper 296, IDS, Brighton.

[17] Mainka, S. and Trivedi, M., Eds. (2002) Links between Biodiversity Conservation, Livelihoods and Food Security: The Sustainable Use of Wild Species of Meat. Occasional Paper of the IUCN Species Survival Commission No. 24. IUCN, Gland, Switzerland and Cambridge, UK.

[18] Friedmann, Y. (2003) Bushmeat—A Southern African Issue Too. Endangered Wildlife, 43, 16-17.

[19] Chardonnet, P., des Clers, B., Fischer, J., Gerhold, R., Jori, F. and Lamarque, F. (2002) The Value of Wildlife. Scientific and Technical Review, Office of International Epizootiology, 21, 15-51.

[20] Bakarr, M.I., Fonseca, G.A.B.D., Mittermeier, R.A., Rylands, A.B. and Painemilla, K.W., Eds. (2001) Hunting and Bushmeat Utilisationin the African Rainforest: Perspectives towards a Blueprint for Conservation Action. Conservation International, Washington DC.

[21] Brown, D. and Davies, G. (2007) Bushmeat and Livelihoods: Wildlife Management and Poverty Reduction. Blackwell Publishers, Oxford. 
[22] Scoones, I., Melnyk, M. and Pretty, J. (1992) The Hidden Harvest: Wild Foods and Agricultural Systems: A Literature Review and Annotated Bibliography. IIED, SIDA and WWF, London.

[23] McShane, T.O. (2003) Protected Areas and Poverty-The Linkages and How to Address Them. Policy Matters (IUCN Commission on Environmental, Economic and Social Policy), No. 12, 52-53.

[24] Norton-Griffiths, M. and Southey, C. (1995) The Opportunity Costs of Biodiversity Conservation in Kenya. Ecological Economics, 12, 125-139. http://dx.doi.org/10.1016/0921-8009(94)00041-S

[25] Fussel, H. (2007) Vulnerability: A Generally Applicable Conceptual Framework for Climate Change Research. Global Environmental Change, 17, 155-167. http://dx.doi.org/10.1016/j.gloenvcha.2006.05.002

[26] O’Brien, K., Eriksen, S., Schjoien, A. and Nygaard, L. (2004) What's in a Word? Conflicting Interpretations of Vulnerability in Climate Change Research. CICERO Working Paper 2004:04, Oslo University, Oslo.

[27] Downing, T.E., Patwardhan, A., Mukhala, E., Stephen, L., Winograd, M. and Ziervogel, G. (2002) Vulnerability Assessment for Climate Adaptation. Adaptation Planning Framework Technical Paper 3. SEI Office, Oxford. www.sei.se/oxford

[28] Liverman, D.M. (1990) Chapter 26: Vulnerability to Global Environmental Change. In: Kasperson, R.E., Dow, K., Golding, D. and Kasperson, J.X., Eds., Understanding Global Environmental Change: The Contributions of Risk Analysis and Management, Clark University, Worcester, 27-44.

[29] Cannon, T. (2000) Vulnerability Analysis and Disasters. In: Parker, D.J., Ed., Floods, Routledge, London, 45-55.

[30] Adger, W.N. (1999) Social Vulnerability to Climate Change and Extremes in Coastal Vietnam. World Development, 27, 249-269. http://dx.doi.org/10.1016/S0305-750X(98)00136-3

[31] DFID (1999) Sustainable Livelihood Guidance Sheets. http://www.eldis.org/vfile/upload/1/document/0901/section2.pdf

[32] Godoy, R., Jacobson, M. and Wilkie, D. (1998) Strategies of Rain-Forest Dwellers against Misfortunes: The Tsimane Indians of Bolivia. Ethnology, 37, 55-71. http://dx.doi.org/10.2307/3773848

[33] Scherr, S.J. (2000) A Downward Spiral? Research Evidence on the Relationship between Poverty and Natural Resource Degradation. Food Policy, 25, 479-498. http://dx.doi.org/10.1016/S0306-9192(00)00022-1

[34] Shackleton, C.M. and Shackleton, S.E. (2004) The Importance of Non-Timber Forest Products in Rural Livelihood Security and as Safety-Nets: A Review of Evidence from South Africa. South African Journal of Science, Rhodes Centenary Issue, 100, 658-664.

[35] Wunder, S. (2001) Poverty Alleviation and Tropical Forests-What Scope for Synergies? World Development, 29, 1817-1833. http://dx.doi.org/10.1016/S0305-750X(01)00070-5

[36] McSweeney, K. (2003) Tropical Forests as Safety-Nets? The Relative Importance of Forest Product Sale as Smallholder Insurance, Eastern Honduras. Proceedings of the International Conference on Rural Livelihoods, Forests and Biodiversity, Bonn, 19-23 May 2003.

[37] McSweeney, K. (2005) Natural Insurance, Forest Access and Compound Misfortune: Forest Resources in Smallholder Coping Strategies before and after Hurricane Mitch, North Eastern Honduras. World Development, 33, 1453-1471. http://dx.doi.org/10.1016/j.worlddev.2004.10.008

[38] Paumgarten, F. (2007) The Significance of the Safety-Net Role of NTFPs in Rural Livelihoods, South Africa. Master's Thesis, Rhodes University, Grahamstown.

[39] Few, R. (2003) Flooding, Vulnerability and Coping Strategies: Local Responses to a Global Threat. Progress in Development Studies, 3, 43-58. http://dx.doi.org/10.1191/1464993403ps049ra

[40] De Waal, A. and Whiteside, A. (2003) New Variant Famine: AIDS and the Food Crisis in Southern Africa. The Lancet, 362, 1234-1237. http://dx.doi.org/10.1016/S0140-6736(03)14548-5

[41] Maxwell, D., Ahiadeke, C., Levin, C., Armar-Klemesu, M., Zakariah, S. and Lamptey, G.W. (1999) Alternative FoodSecurity Indicators: Revisiting the Frequency and Severity of "Coping Strategies". Food Policy, 24, 411-429. http://dx.doi.org/10.1016/S0306-9192(99)00051-2

[42] Wong, G.Y. and Godoy, R. (2003) Consumption and Vulnerability among Foragers and Horticulturalists in the Rainforest of Honduras. World Development, 31, 1405-1419. http://dx.doi.org/10.1016/S0305-750X(03)00099-8

[43] Dekker, M. (2004) Sustainability and Resourcefulness: Support Networks during Periods of Stress. World Development, 32, 1735-1751. http://dx.doi.org/10.1016/j.worlddev.2004.06.002

[44] Heemskerk, M., Norton, A. and De Dehn, L. (2004) Does Public Welfare Crowd out Informal Safety Nets? Ethnographic Evidence from Rural Latin America. World Development, 32, 941-955. http://dx.doi.org/10.1016/j.worlddev.2003.11.009

[45] Smith, D.R., Gordon, A., Meadows, K. and Zwick, K. (2001) Livelihood Diversification in Uganda: Patterns and De- 
terminants of Change across Two Rural Districts. Food Policy, 26, 421-435.

http://dx.doi.org/10.1016/S0306-9192(01)00012-4

[46] De Jong, W., Campbell, B.M. and Schroder, J.M. (2000) Sustaining Incomes from Non-Timber Forest Products: Introduction and Synthesis. International Tree Crop Journal, 10, 267-275. http://dx.doi.org/10.1080/01435698.2000.9753015

[47] Kepe, T. (2002) Grassland Vegetation and Rural Livelihoods: A Case Study of Resource Value and Social Dynamics on the Wild Coast, South Africa. Ph.D. Thesis, University of the Western Cape, Cape Town.

[48] Dovie, D.B.K. (2003) Rural Economy and Livelihoods from the Non-Timber Forest Products Trade. Compromising Sustainability in Southern Africa? International Journal of Sustainable Development World Ecology, 10, 247-262. http://dx.doi.org/10.1080/13504500309469803

[49] De Merode, E., Homewood, K. and Cowlishaw, C. (2004) The Value of Bushmeat and Other Wild Foods to Rural Households Living in Extreme Poverty in Democratic Republic of Congo. Biological Conservation, 118, 573-581. http://dx.doi.org/10.1016/j.biocon.2003.10.005

[50] Shackleton, S.E. (2005) The Significance of the Local Trade in Natural Resources Products for Livelihoods and Poverty Alleviation in South Africa. Ph.D. Thesis, Rhodes University, Grahamstown.

[51] Pattanayak, S.K. and Sills, E.O. (2001) Do Tropical Forests Provide Natural Insurance? The Microeconomics of Non-Timber Forest Product Collection in the Brazilian Amazon. Land Economics, 77, 595-612. http://dx.doi.org/10.2307/3146943

[52] Ros-Tonen, M.A.F. and Wiersum, K.F. (2003) The Importance of Non-Timber Forest Products for Forest-Based Rural Livelihoods: An Evolving Research Agenda. A Paper Presented at the International Conference on Rural Livelihoods, Forests and Biodiversity, Bonn, 19-23 May 2003.

[53] Block, S. and Webb, P. (2001) The Dynamics of Livelihood Diversification in Post-Famine Ethiopia. Food Policy, 26, 333-350. http://dx.doi.org/10.1016/S0306-9192(01)00015-X

[54] McKenzie, D.J. (2003) How Do Households Cope with Aggregate Shocks? Evidence from the Mexican Peso Crisis. World Development, 31, 1179-1199. http://dx.doi.org/10.1016/S0305-750X(03)00064-0

[55] Mock, C.N., Gloyd, S., Adjei, S., Acheampong, F. and Gish, O. (2003) Economic Consequences of Injury and Resulting Family Coping Strategies in Ghana. Accident Analysis and Prevention, 35, 81-90. http://dx.doi.org/10.1016/S0001-4575(01)00092-6

[56] Lukhele, A.K. (1990) Stokvels in South Africa. AMAGI Books, Johannesburg.

[57] Denzin, N. and Lincoln, Y., Eds. (1994) Handbook of Qualitative Research. Sage, Thousand Oaks.

[58] Yin, R.K. (2003) Case Study Research: Design and Methods. Sage Publications, London.

[59] Neuman, W.L. (2003) Social Research Methods: Qualitative and Quantitative Approaches. Allyn and Bacon, New York.

[60] Gillham, B. (2000) Case Study Research Methods. Continuum, London.

[61] Oates, J.F. (1995) The Dangers of Conservation by Rural Development: A Case Study from the Forests of Nigeria. Oryx, 29, 115-122. http://dx.doi.org/10.1017/S0030605300020986

[62] Oates, J.F. (1999) Myth and Reality in the Rainforest: How Conservation Strategies Are Failing in West Africa. University of California Press, Berkeley.

[63] Rabinowitz, A. (1999) Nature's Last Bastions: Sustainable Use of Our Tropical Forests May Be Little More than Wishful Thinking. Journal of Natural History, 108, 70-72.

[64] Terborgh, J. (1999) Requiem for Nature. Island Press/Shearwater Books, Washington DC.

[65] Agrawal, A. and Redford, K. (2006) Poverty, Development and Biodiversity Conservation: Shooting in the Dark? Working Paper No. 26, Wildlife Conservation Society.

[66] Naughton-Treves, L., Holland, M.B. and Brandon, K. (2005) The Role of Protected Areas in Conserving Biodiversity and Sustaining Local Livelihoods. Annual Review of Environment and Resources, 30, 219-252. http://dx.doi.org/10.1146/annurev.energy.30.050504.164507

[67] Fortwangler, C.L. (2003) The Winding Road: Incorporating Social Justice and Human Rights into Protected Areas Policies. In: Brechin, S.R., Wilhusen, P.R., Fortwangler, C.L. and West, P.C., Eds., Contested Nature: Promoting International Biodiversity with Social Justice in the Twenty-First Century, State University of New York Press, New York, 25-39.

[68] Holmes, G. (2007) Protection, Politics and Protest: Understanding Resistance to Conservation. Conservation and Society, 5, 184-211.

[69] Naguran, R. (2002) Property Rights and Protected Areas: The Case of Ndumo Game Reserve. Proceedings of the Re- 
search Seminar on Property Rights and Environmental Degradation, Durban, 27-30 May 2002.

[70] Magome, H. and Murombedzi, J. (2003) Sharing South African National Parks: Community Land and Conservation in a Democratic South Africa. In: Adams, W.M. and Mullingan, M., Eds., Decolonizing Nature-Strategies for Conservation in a Post-Colonial Era, Earthscan Publications Ltd., London.

[71] Naughton-Treves, L. and Sanderson, S. (1995) Property, Politics and Wildlife Conservation. World Development, 23, 1265-1275. http://dx.doi.org/10.1016/0305-750X(95)00045-E 
Scientific Research Publishing (SCIRP) is one of the largest Open Access journal publishers. It is currently publishing more than 200 open access, online, peer-reviewed journals covering a wide range of academic disciplines. SCIRP serves the worldwide academic communities and contributes to the progress and application of science with its publication.

Other selected journals from SCIRP are listed as below. Submit your manuscript to us via either submit@scirp.org or Online Submission Portal.
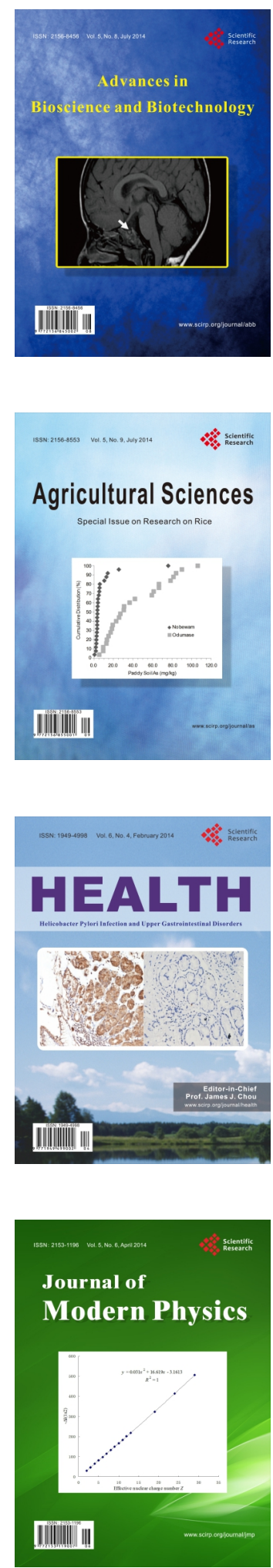
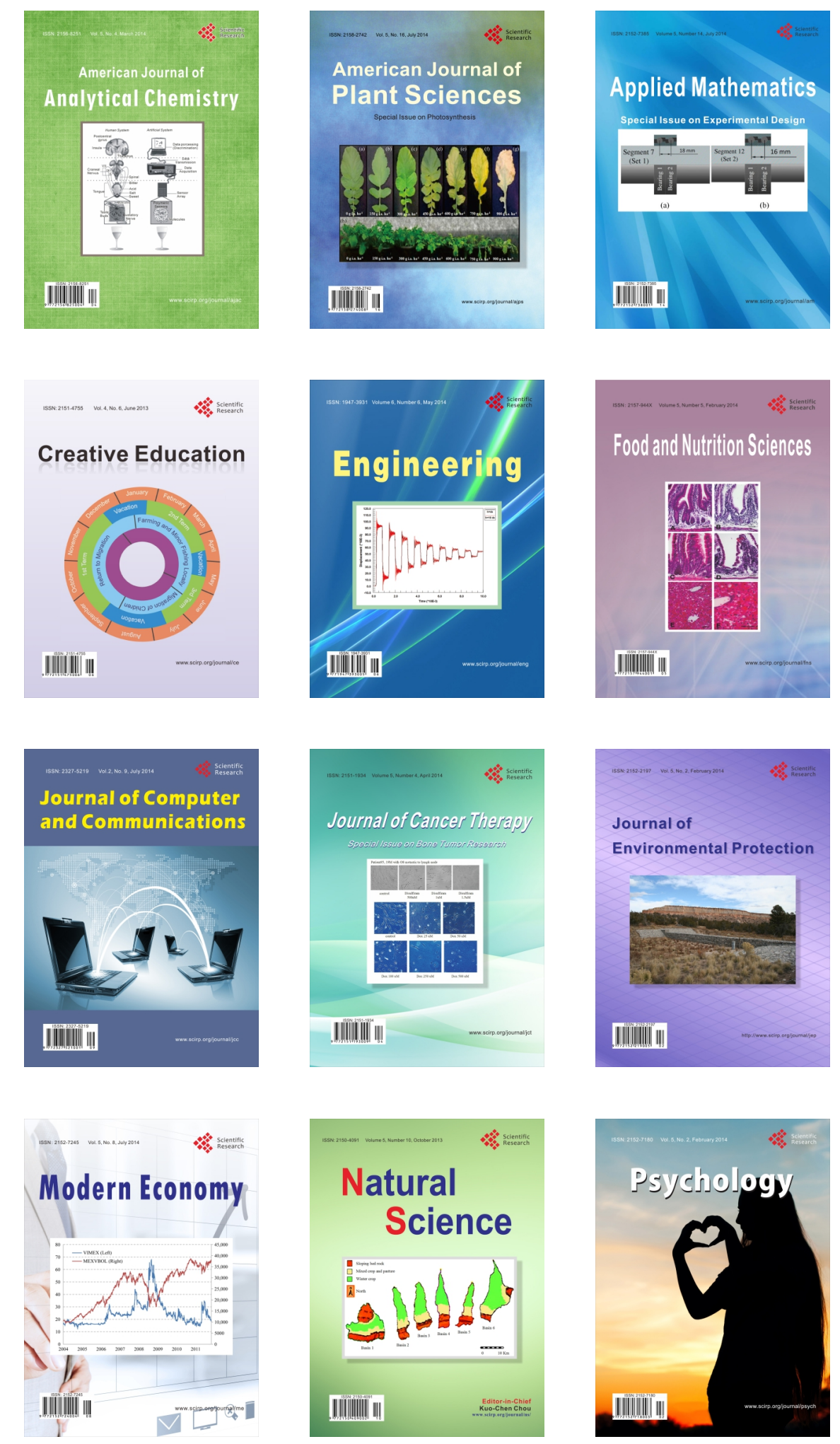